BISMA

(Bisnis dan Manajemen)
Volume 13, Issue 2, April 2021, 135-147

ISSN 2549-7790 (Online)

ISSN 1979-7192 (Print)

DOI: 10.26740/bisma.v13n2.p 135-147

https://journal.unesa.ac.id/index.php/bisma/index

\title{
Monetary policy and stock market reaction: developed market and emerging market comparison
}

\author{
Buddi Wibowo* \\ University of Indonesia, Indonesia
}

\begin{abstract}
This research examines the correlation between monetary policy and stock market reaction. Monetary policy is represented by short term interest rate and exchange rate to USD. This quantitative research uses OLS Regression, SUR, and Panel Regression Method. The results suggest that monetary policy affects the movement of the stock market return. Using OLS and SUR, this study finds that short-term interest rates have a significant negative correlation to return, and exchange rates positively correlate with returning. Using the Panel Data Model, this study finds that short-term interest rates have significant correlations in G7 and emerging countries. Still, the exchange rate is only significant in the emerging market. With SUR, there are common factors that affect the global return to move together. Domestic monetary policy is not an effective tool to influence the stock market because there are common factors in a region. From a financial management perspective, this result gives a practical reason for an investor to create an optimal portfolio through regional stock market diversification. Considering monetary policy in a country as a crucial factor in rebalancing the portfolio, standard regional monetary policy becomes an appropriate strategy.
\end{abstract}

Keywords: emerging market; monetary policy; stock market; transmission.

Received: June 19, 2020; Accepted: August 31, 2020; Published April 29, 2021

*Corresponding author

Email: buddi.wibowo@ui.ac.id

\section{To cite this document:}

Wibowo, B. (2021). Monetary policy and stock market reaction: developed market and emerging market comparison. BISMA (Bisnis dan Manajemen), 13(2), 135-147. https://doi.org/10.26740/bisma.v13n2.p135-147.

\section{INTRODUCTION}

Debates among academics and policymakers about the relationship between monetary policy and financial market development have not reached a consensus (Abouwafia \& Chambers, 2015; Bjørnland \& Leitemo, 2009). The starting point of the debate lies in the impact of financial assets price fluctuation on the real sector, especially on economic output growth and inflation (Ioannidis \& Kontonikas, 2008). However, all parties in the debate agree that the monetary policy objectives are macroeconomic stability, growth, and community welfare improvement. Nevertheless, achieving these objectives has not been agreed upon yet 
(Neuhierl \& Weber, 2019; Marinescu et al., 2018; Gong \& Dai, 2017; Lawal et al., 2018). Monetary policy directly affects the money supply, interest rates, and financial assets price to rise and fall, distorting investment and consumption decisions. It could bring excessive fluctuations to economic output and inflation (Laopodis, 2013). Proactive monetary policy proponents suggest that monetary authority must always be ready to react when there is the disequilibrium of financial instrument prices which may drive financial markets price away from their fundamental value. Economics bubbles in financial markets may threaten macroeconomic stability and need to be directed through proper monetary policy (Chatziantoniou et al., 2013). The rise and fall of the interest rate set by the monetary authority are directly related to the market price of financial instruments (Caraiani \& Călin, 2020).

Conversely, opponents criticise the proactive monetary policy as challenging to execute by the monetary authority. They should identify the wrong market prices and restore them to their fundamental intrinsic value. Improper government intervention to market mechanism is worsening the economic problem. The previous researchers state that monetary policy should only be reactive toward price movements that threaten output and inflation stability (Bernanke \& Gertler, 2001; Bouakez \& Normandin, 2010). Monetary policy is being set up based on expost financial market data.

Both proactive and reactive monetary policy uses the same assumption, monetary policy significantly influences financial market conditions. The monetary policy depends on the financial asset prices reaction toward monetary policy instruments. The effectiveness of monetary policy depends on the robust understandings of monetary policy and financial market relationship.

The relationship analysis of monetary policy and financial markets becomes more complex with cointegration between financial markets in a region, the interplay between a country's domestic monetary policy, and policies taken by global countries (Bekaert et al., 2008; Abouwafia \& Chambers, 2015). In the Indonesian context, this problem is very prominent because Indonesia has a free foreign exchange regime so that the flow of money can enter freely and foreign ownership in the Indonesian bond and stock market is very significant.

An empirical test of the effects caused by a monetary policy has the main problem: monetary transmission lag time. Banking interest and exchange rates set by the monetary authority show the effectiveness of monetary policy in a country (De Bondt, 2005; Karagiannis, Panagopoulos, \& Vlamis, 2010; Abouwafia \& Chambers, 2015).

De Bondt (2005) measured interest rate pass-through in Euro countries. Meanwhile, Karagiannis, Panagopoulos, \& Vlamis (2010) observed frictions of monetary policy transmission mechanism, so that bank interest rate reacts slowly to monetary policy changes in Latin America. The latest researches from Wibowo \& Lazuardi (2016) in Indonesia, Abouwafia \& Chambers (2015) in Arabian Gulf countries, and Rocha (2012) in Portugal, found a similar result but with different determinant factors. Factors that influence interest rate passthrough are specific for each country because of different conditions of the banking industry, the non-bank financial industry, the capital market development, and the financial system. Different friction causes different interest rate pass-throughs between countries. This complexity makes some empirical tests of the relationship between monetary policy and the stock market bear the mixed results. Several researchers that use data from various countries 
Monetary policy and stock market reaction: developed market and emerging market comparison

find sharp differences. For examples, Laopodis (2013) found no consistent dynamic correlation between monetary policy and the stock market. Different observation periods show a contradicting result. Bouakez \& Normandin (2010) showed that the global financial market excess liquidity created by expansive monetary policy in developed countries has a significant positive impact on stock price movements in emerging and developed markets.

However, Ioannidis \& Kontonikas (2008) observed that thirteen OECD countries find the majority of those countries experienced a significant decline in domestic stock market value in the contractionary monetary policy period. Bjørnland \& Leitemo (2009), who observed the US around the period of the economic crisis 2008, have similar findings with Ioannidis \& Kontonikas (2008) that expanding the money supply creates a boom in the stock market. It isn't easy to make a valid comparison between the results of the above studies because they use different observation periods so that the changing global monetary conditions in each period may affect the results.

To answer the controversies and research gaps from the above explanation, we observe data from developing and developed countries in the same period. This research uses data from the top five emerging market versions of the Global Intelligence Alliance (GIA, 2012), namely India, Brazil, China, Russia, and Indonesia. For the OECD countries, this research uses all G7 member countries. This study also observes a common factor that makes share prices move together between G7 countries and emerging markets. This study confirms whether, in the twelve observed countries over the past two decades, a common factor that significantly drives stock market returns altogether exist. It is essential to identify common factors among stock markets in this research context because the effectiveness of monetary policy to influence stock market depends on the existence of common factors which influence all stock market regionally and globally, and direct it to the opposite direction (Abouwafia \& Chambers, 2015; Chatziantoniou, Duffy, \& Filis, 2013).

This study uses a regression model with OLS estimation methods and Data Panel Model, and the Seemingly Unrelated Regression (SUR) model to test common factors among the stock markets. The period of the 2008 monetary crisis also includes the study to analyse the relationship of monetary policy to the stock market in advanced economies (G7) and developing countries over the past twenty years with a range of research period from 1996 to 2018. The range of this period is taken to obtain a comprehensive observation of the relationship between monetary policy and the stock market in the long run. There is a period of global crisis (1998 and 2008). Hence, we can argue whether the stock market index return is significantly affected by monetary policy or not during the past two decades. The empirical results may give fund managers insight into creating an optimal portfolio through regional stock market diversification. Instead of taking the specific and national monetary policy to rebalance the investment portfolio, considering the standard regional monetary policy is more appropriate.

\section{Interest Rate Movement on Nominal Stock Market Return Reaction in Developed and Emerging Countries}

Karagiannis et al. (2010) found the monetary policy in Latin America has a low impact on the bank interest rate. Wibowo \& Lazuardi (2016) in Indonesia, Abouwafia \& Chambers (2015) in Arabian Gulf countries, and Rocha (2012) in Portugal also found similar results that 
bank interest rate only slightly influenced by monetary policy and show such underreaction to monetary authority moves. Previous research shows that proactive monetary policy fails to direct bank interest rates and marginalize the domestic stock market in emerging countries.

However, Ioannidis \& Kontonikas (2008) observed developed countries find domestic stock market value is influenced and driven by monetary policy. Bjørnland \& Leitemo (2009), who observed the US around the period of the economic crisis 2008, found The Federal reserves' quantitative easing which greatly expands the money supply, has a significant effect on the US stock market all world stock market also. Proactive monetary policy relatively succeeds in driving stock market return in developed countries. Contradicting previous research on emerging market return, the stock market in developed markets has a strong relation with monetary policy and reflects the impact quickly.

H1: There is a different impact of interest rate movement on nominal stock market return reaction in developed and emerging countries.

\section{Exchanges Rate on Nominal Stock Market Return Reaction in Developed and Emerging Countries}

Monetary policy influences the stock market through two channels: interest rates and exchanges rates (Bekaert et al., 2008). Expansionary (contractionary) monetary policy influences the real sector through money supply increases (decreases). Money supply directly affects market interest rates, which is an essential factor in pushing investment in the real sector or the stock market investment portfolio. Money supply also plays a crucial role in directing the exchange rate of local currency to other/global currencies. From global investors' perspective, exchange rate risk is a central problem in making an optimal global investment portfolio (Neuhierl \& Weber, 2019).

Emerging stock markets recently have been a more important investment target for global investors are susceptible to exchange rate fluctuation (Neuhierl \& Weber, 2019; Marinescu et al., 2018). Weak and volatile local currency makes a stock market return in that country with high exchange rate risk exposure. Global investors need a higher compensation to allocate an investment portfolio in the emerging stock market because of higher exchange rate risk exposure (Gong \& Dai, 2017). In a developed market with a more stable local currency, the monetary policy effectively transmits a clear signal to the stock market, which is a future policy direction. Emerging market has a more complex market environment (Lawal et al., 2018), which is not only local currency movement that global investors consider when deciding to invest in such a market but also must predict the dominant global currency movement significant impact on that emerging stock market return.

$\mathrm{H} 2$ : There is a different impact of exchanges rate on nominal stock market return reaction in developed and emerging countries.

\section{Interest Rate on Real Market Return Reaction in Developed and Emerging Countries}

All previous research focuses on the interest rate impact on nominal market return, rather than the real market return, which considers the level of inflation impact in each country (Neuhierl \& Weber, 2019). Inflation level may undermine real return that investor receives (Chatziantoniou et al., 2013). The investor will strongly react to interest rate risk, decreasing 
Monetary policy and stock market reaction: developed market and emerging market comparison

their real return. In a high inflation environment, interest rate movement has a more significant impact on real market return. Emerging countries that usually have high inflation levels have different interest rate impacts on real market return than developed markets with lower inflation rates (Bouakez \& Normandin, 2010). Real return is more important for a global investor than a nominal return. They consider a monetary policy that significantly affects future real market return and is crucial in determining their global optimal investment portfolio (Lawal et al., 2018). We may hypothesize that real return has a higher risk in the emerging market because of their higher inflation level than the developed market.

H3: There is a different impact of interest rate on real market return reaction in developed and emerging countries.

\section{Exchanges Rate on Real Market Return Reaction in Developed and Emerging Countries}

From the global investor point of view, the real return is more important than the nominal return. Monetary policy that influences real return is an essential factor in determining a global investment portfolio (Lawal et al., 2018). Instead of testing the significant impact of exchange rate movement on nominal market return, we hypothesise that real return is a more appropriate variable that plays a vital role in directing global investors to allocate their funds to emerging markets. Correlation between stock market real return is an essential factor for international investors to allocate their funds among emerging markets to get an optimal investment portfolio. Some papers have already revealed that common factors simultaneously affect stock market return in emerging market (Karagiannis et al., 2010). Their results have researched monetary policy effectiveness in directing stock market movement to regulator's favourable level more complex (Marinescu et al., 2018; Gong \& Dai, 2017). Different inflation level among countries which make a significant different real return should be a decisive factor for the global investor (Abouwafia \& Chambers, 2015; Chatziantoniou, Duffy, \& Filis, 2013).

H4: There is a different impact of exchanges rate on real market return reaction in developed and emerging countries.

\section{METHODS}

This research observes 2009-2018 data from five developing countries: India, Brazil, China, Russia, and Indonesia. G7 countries are the US, the UK, Japan, Germany, France, Italy, and Canada. The observed data is the short-term interest rate. For G7 countries, this study uses three months Treasury Bill and policy rates of the monetary authorities or central banks of each country for emerging countries. We also use stock market index data per country, the exchange rate against the US Dollar, and the inflation rate. Data is obtained through Data Stream Thompson Reuters. Time series is first tested for stationarity at the level and first difference with or without index and intercept using Augmented Dickey-Fuller (ADF) and KPPS tests. The empirical model of the research is:

Return $_{i, t}=$ Interest $_{i, t}+$ Exchange Rate $_{i, t}+e_{i, t}$

Return is the yield of the stock market index of each country. Interest is the interest rate that reflects the monetary policy of the bank lending channel line, and the exchange rate is the exchange rate of each country against the US dollar, which reflects monetary policy from the exchange rate path. 
Stock market index returns are measured in two ways: nominal return and real return. The real return is the nominal return minus the monthly inflation rate in each country. Model (1) is estimated using two estimation methods: the Ordinary Least Square and Panel Data Model.

To test the existence of common factors that influence stock market price index returns, we use the SUR model, estimated using Eviews software. SUR is a system of equations that contains several regression equations that are estimated separately, but the error term produced by each equation has a high correlation. Measurement of the correlation between error terms in this study was done manually by forming a correlation matrix (Fiebig, 2007).

\section{RESULTS AND DISCUSSION}

Table 1 displays the monthly return statistics for the stock market index of 12 sample countries during the 20 -years observation period. The average monthly stock return is high for all emerging market country categories, namely Russia, Brazil, Indonesia, India and China. The highest average return is Russia which reaches $1.8 \%$ per month. The average return of the stock market index of G7 countries, France, the UK, the US, Germany, Canada, Italy, and Japan, is far lower than emerging market countries. Japan and Italy are the lowest among observed countries. However, investment in emerging country's stock exchanges has a higher risk than in developed countries. The highest standard deviation of return is all in five observed developing countries.

Table 1. Monthly Nominal Return of Stock Market Index

\begin{tabular}{lrrrrrr}
\hline & Average & Median & Maximum & Minimum & $\begin{array}{c}\text { Standard } \\
\text { Deviation }\end{array}$ & $\begin{array}{c}\text { Correlation } \\
\text { with the US } \\
\text { Stock Market } \\
\text { Return }\end{array}$ \\
\hline UK & 0.0030 & 0.0067 & 0,614583333 & -0.1302 & 0,280555556 & 0,054861111 \\
Indonesia & 0,086111111 & 0,120833333 & 1,973611111 & -0.3151 & 0,553472222 & 00.47 \\
India & 0,079166667 & 0,070833333 & 1,961805556 & -0.2389 & 0,500694444 & 00.40 \\
Russia & 0,127777778 & 0,16875 & 3,891666667 & -0.6729 & 0,920138889 & 00.31 \\
US & 0.0061 & 0.0098 & 0,715972222 & -0.1416 & 0,283333333 & 01.00 \\
Japan & 0.0014 & 0.0053 & 0,891666667 & -0.2382 & 0,392361111 & 00.51 \\
Italy & 0.0012 & 0.0043 & 1,460416667 & -0.2905 & 0,484027778 & 00.49 \\
Brazil & 0,093055556 & 0,099305556 & 1,669444444 & -0.3955 & 0,589583333 & 00.58 \\
France & 0.0053 & 0,083333333 & 0,93125 & -0.1749 & 0,381944444 & 0,050694444 \\
Canada & 0.0052 & 0,071527778 & 0,821527778 & -0.2020 & 0,303472222 & 0,047916667 \\
China & 0,077083333 & 0.0072 & 2,225694444 & -0.2463 & 0,573611111 & 00.18 \\
Germany & 0.0086 & 0,1 & 1,484027778 & -0.2542 & 0,443055556 & 0,050694444 \\
\hline
\end{tabular}

Stock markets in developed countries correlated very strongly with the movement of the US stock market returns. France, Germany, and the UK stock market have the strongest correlation with US stock market return. Cointegration of the US stock market and big European countries has been documented by several researchers such as Morana \& Beltratti (2008). This cointegration is caused by the high flow of funds among those countries, not only in the form of portfolio investment in the financial market but also in trade relations and foreign direct investment (Mobarek et al., 2016). We find a moderate correlation with the US stock market between 0.4 and 0.6, which occurs in Italian, Brazilian, Indian, Indonesia, and Japanese stock markets. While Russia and China have a much lower level of return relationship with the 
Monetary policy and stock market reaction: developed market and emerging market comparison

US market because the development of the stock exchanges in the two communist countries is still at the stage of consolidation after the centralised economic regime of communism, they left behind. According to Morana \& Beltratti (2008), the strong correlation between world stock exchanges is mainly due to the global business cycle and increasingly interconnected world economy.

\section{Interest Rate on Stock Market}

Table 2 shows a negative relationship between interest rates and nominal stock market index return in eight countries: Indonesia, India, Russia, China, the UK, Canada, Japan, and the US. Interest rate policy has a direction that is contrary to the movement of the stock market index. Interest rates are a monetary tool that should direct funds into and out of the stock markets. Still, we find a significant relationship between nominal interest rates and stock market index returns in Indonesia and the UK at the level of error of 5\%. The effect of interest rates on stock market return is much greater if the stock market return is measured as real return, nominal return minus the domestic inflation rate. Regression coefficients in countries with negative coefficients show negative movement interest rates against the stock market index, experiencing a substantial increase if the dependent variable is real returns.

The significance level of the coefficient also increases in countries that have the opposite direction between interest rates and the stock market index. Some countries whose regression coefficient is not significant in the interest rate variable will be significant if the dependent variable is real returns. This shows that the country's domestic inflation rate strongly influences the flow of funds in and out of a country's stock exchange. Global investors are more interested in real yields than nominal yields, especially in countries with significant foreign ownership (Mobarek et al., 2016).

The number of countries with positive regression coefficients has interest rate variables equal to those with negative coefficients. This finding reinforces the findings of previous researchers who showed different patterns of relations between countries because of the specific conditions that exist in each country (Morana \& Beltratti, 2008; Mobarek et al., 2016).

Developed countries dominate countries with a significant relationship between interest rates and returns of the stock market index; for developing countries, only Indonesia and India have a significant and positive coefficient. This shows the reaction of stock market investors to the interest rate policy set by the monetary authority much faster and significantly in developed countries. In developing countries, monetary transmission needs more time to cause a significant effect on stock markets, the influence of the benchmark interest rate does not directly affect every month.

\section{Exchange Rate on Stock Market}

Table 2 shows that exchange rates positively influence stock market returns in only five countries: Indonesia, India, China, Canada, and Italy, but it is significant only in India. Positive influence means the stronger the country's exchange rate against USD, the stock market index has a significant increase. Strengthening a country's exchange rate is often associated with investor sentiment towards the country's economic prospects (Kurov, 2010). We need to examine whether stock market index increases directly affect monetary policy or just an investor's sentiment changes (Bouakez \& Normandin, 2010). 
If we use the real stock market index, which is nominal return minus domestic inflation, all regression coefficients in developing countries will be significant. This shows that investors in the stock market react more strongly to the movement of real return rather than nominal return, especially in emerging market stock exchanges. Developed stock markets that have experienced changes in coefficient significance are only three countries, namely the UK, Canada, and Italy.

Table 2. Regression Result

\begin{tabular}{|c|c|c|c|c|}
\hline \multirow{2}{*}{$\begin{array}{r}\text { Dependent } \\
\text { Variables } \\
\text { (Country) }\end{array}$} & \multicolumn{2}{|c|}{ Nominal Stock Market Return } & \multicolumn{2}{|c|}{ Real Stock Market Return } \\
\hline & $\begin{array}{c}\text { Interest } \\
\text { Rate }\end{array}$ & $\begin{array}{c}\text { Foreign Exchanges } \\
\text { Rate }\end{array}$ & $\begin{array}{c}\text { Interest } \\
\text { Rate }\end{array}$ & $\begin{array}{c}\text { Foreign Exchanges } \\
\text { Rate }\end{array}$ \\
\hline Brazil & 0.7 & -1.2 & 0.9 & $-1.4^{*}$ \\
\hline Indonesia & $-0.8 * *$ & 1.7 & $-1.1^{* *}$ & $1.9^{*}$ \\
\hline India & -1.0 & $1.3^{*}$ & $-1.3^{*}$ & $1.9 * *$ \\
\hline Russia & -0.5 & 2.1 & -0.6 & $2.3^{*}$ \\
\hline China & -0.3 & 0.8 & -0.5 & $1.3^{*}$ \\
\hline UK & -0.9 & -0.9 & $-1.2 *$ & $-1.1^{*}$ \\
\hline Canada & -0.7 & 0.9 & $-0.9 *$ & $1.2 *$ \\
\hline Italy & 0.4 & 1.4 & 0.5 & $1.5^{*}$ \\
\hline Japan & -0.2 & -0.3 & $-0.4 *$ & -0.5 \\
\hline Germany & 0.8 & -0.7 & 0.9 & -0.8 \\
\hline France & -0.5 & -0.7 & -0.7 & -0.9 \\
\hline US & $-1.3^{* *}$ & -- & $-1.4 * * *$ & -- \\
\hline
\end{tabular}

Note:

* $\quad$ Significant at the level of error $10 \%$

** Significant at the level of error $5 \%$

*** Significant at the level of error $1 \%$

Table 2 shows that among the 12 observed countries, there is an absence of foreign exchange rate data of the US. Furthermore, the interest rate positively influences nominal stock return in two among 11 countries (2/11) and on real stock market return in six among twelve countries (6/12). Meanwhile, the foreign exchange rate positively influences real stock market return in one among 11 countries (1/11) and on real stock market return in eight among eleven countries $(8 / 11)$.

The stock market index return increased in most developing countries in the same period, allegedly caused by co-movement. The movement of global fund drove it flows to developing countries which yield a far higher return than the stock markets in developed countries (Bjørnland \& Leitemo, 2009). This movement is allegedly due to positive global investor sentiment towards the economy and developing countries' stock exchanges, as reflected in the strengthening and stability of the developing country's exchange rates.

Countries with an insignificant regression coefficient of interest rate or exchange rate or on both variables simultaneously have other explanatory variables that are more significant in influencing the nominal and real market index yields that are not included in the equation. This study only focuses on interest rates and exchange rates because they assume that these two variables are macro variables that the state can control through monetary policy. The monetary and global, and regional financial markets that influence the movement of a country's market index are not included in the model and will be reflected in the error terms of the 12 regression equations that are estimated separately for each sample country. in the method. Twelve 
Monetary policy and stock market reaction: developed market and emerging market comparison

regression equations seem not to be interconnected, but because there is a strong correlation between error terms resulting from each of the twelve equations, they have a common factor. The common driving factor between the stock exchanges is usually unobservable. It requires a separate effort to measure it and include it as one of the variables in a regression equation. The common factor is investor sentiment (Kurov, 2010), people confidence to government economic policy (Bernanke \& Gertler, 2001), and global financial market (Zare \& Azali, 2015) which all are not an observable data and need a scientific method and procedure to get its quantitative measures.

Table 3. Matrix of Residual Correlation (Seemingly Unrelated Regression)

\begin{tabular}{|c|c|c|c|c|c|c|c|c|c|c|c|c|}
\hline & Brazil & Indonesia & India & Russia & China & UK & Canada & Italy & Japan & Germany & France & US \\
\hline Brazil & 1.000 & & & & & & & & & & & \\
\hline Indonesia & 0.423 & 1.000 & & & & & & & & & & \\
\hline India & 0.426 & 0.339 & 1.000 & & & & & & & & & \\
\hline Russia & 0.430 & 0.306 & 0.339 & 1.000 & & & & & & & & \\
\hline China & 0.222 & 0.181 & 0.207 & 0.184 & 1.000 & & & & & & & \\
\hline UK & 0.576 & 0.454 & 0.353 & 0.365 & 0.146 & 1.000 & & & & & & \\
\hline Canada & 0.563 & 0.383 & 0.367 & 0.328 & 0.159 & 0.660 & 1.000 & & & & & \\
\hline Italy & 0.424 & 0.302 & 0.264 & 0.197 & 0.153 & 0.609 & 0.434 & 1.000 & & & & \\
\hline Japan & 0.456 & 0.459 & 0.362 & 0.282 & 0.228 & 0.519 & 0.465 & 0.470 & 1.000 & & & \\
\hline Germany & 0.558 & 0.466 & 0.357 & 0.285 & 0.191 & 0.779 & 0.613 & 0.657 & 0.523 & 1.000 & & \\
\hline France & 0.577 & 0.446 & 0.351 & 0.313 & 0.185 & 0.790 & 0.611 & 0.663 & 0.533 & 0.874 & 1.000 & \\
\hline US & 0.519 & 0.429 & 0.329 & 0.274 & 0.156 & 0.751 & 0.611 & 0.465 & 0.480 & 0.697 & 0.668 & 1.000 \\
\hline
\end{tabular}

Table 3 displays the correlation matrix of residual or error term from twelve regression equations previously estimated. The strongest error-term correlation was the correlation between German and French error terms of 0.87. As the two countries with the largest economies in Europe and geographically adjacent, the economies of Germany and France are very closely related. Besides, the UK has a strong error correlation with Canada, Italy, Germany, France and the US, with a correlation range of 0.6-0.80. This finding reinforces that the UK is a financial hub among European countries and is also a liaison with North American countries. Italy also has a fairly strong correlation with France and Germany, with a correlation of around 0.6 and 0.66. Although Italy's welfare is relatively behind compared to other developed countries, its economy is recorded as the third-largest after Germany and France. The Italian economy plays a fairly central role in Europe and significantly influences neighbouring countries. Indonesia has an error correlation term with moderate qualifications with all observation countries except China.

In general, correlations of residuals show a strong common factor exists, especially in G7 countries that correlate residual more than 0.6 . The common factor may come from a similar business cycle that affects all stock markets because of close business relations, stock market liquidity closely related, especially in European countries that use the same currency, the Euro. Besides, we find medium and low residuals correlation in emerging market countries, which indicates the cointegration of the stock market in emerging markets is not solid. The determinants of stock market returns in each developing country are unique. Each country has its own and different factors. Morana dan Beltratti (2008) researched 1973-2004 stock market movements in developed countries, such as the UK, the US, Japan, and Germany. Bilateral 
trade flows are a significant determinant of the shock transmission from a developed country to other stock and bond markets (Zare \& Azali, 2015).

To examine the differences in the stock market reaction to monetary policy between developing and developed countries more deeply, we also estimate a separate panel data model between the two countries. This research uses the fixed effect model as the best model based on the model selection test to determine the best model for panel data. Both in developed markets and emerging markets, interest rates and exchange rates significantly influence nominal returns. However, it does not apply to real returns, interest rates and exchange rates, which do not significantly affect the real return of the emerging stock market. With a higher and unpredictable inflation rate, the real return of the emerging stock market may be a drift away from the nominal return. Investor sentiment plays a vital role in the emerging market, especially in turbulent periods, monetary policy may have no significant impact in such condition.

This result supports previous studies such as Karagiannis et al. (2010) and Abouwafia \& Chambers (2015). Managing stock portfolio investment risk faces a different challenge in the developed market than the emerging stock market. Real return in the emerging market depends on foreign exchanges fluctuation in each country. Investment managers or business entities should take the result of the study as a precaution that an effective financial management strategy depends on accurate anticipation of monetary policy impact on stock market price movement and deep comprehension of some distinctive factors in each stock market.

\section{CONCLUSIONS}

Based on the results which we find and discuss above, we conclude that all hypotheses, $\mathrm{H} 1, \mathrm{H} 2, \mathrm{H} 3$ and H4, are supported by empirical data we observe. Proactive monetary policies that influence interest rate and exchanges rate, impact the emerging stock market and developed market.

Monetary policy in some G7 countries is relatively ineffective in influencing the domestic stock market because investors in most developed countries stock markets are not limited to domestic investors. They become an investment destination for global investors. Monetary policy in developing countries was strongly influenced by the domestic inflation factors, which made monetary policy quite influence the movement and development of the stock market.

The empirical test results show that common factors influence interest rate policies and exchange rates with stock market returns. This common factor makes monetary policy less effective in influencing the stock market. Economic and non-economic variables such as investor sentiment and herding behavior need to be examined further.

The practical implication of the results of this research is that proactive monetary policy to direct the development and development of the stock market is very difficult to implement because of the slow stock market reaction to monetary policy direction. It is presumably due to monetary friction in the form of slow pass-through interest rates. The monetary transmission mechanism to the real sector through financial markets is hampered. Because of global and regional common factors, each country's monetary policy must also consider the monetary policies launched by other countries. This result shows that mitigation stock market risk needs 
Monetary policy and stock market reaction: developed market and emerging market comparison a broad comprehension of monetary and macroeconomics policy and various distinctive factors in each stock market.

There are country-specific factors that influence the effect of monetary policy on stock market development in each country which is not observed in this study, such as government regulation on stock market development, stock market transparency, and investor protection law. Further study should consider and deeply observe these important factors' influence to reveal more comprehensive findings.

\section{REFERENCES}

Abouwafia, H. E. \& Chambers, M. J. (2015). Monetary Policy, Exchange Rates and Stock Prices in the Middle East Region. International Review of Financial Analysis, 37, 14-28. https://doi.org/10.1016/j.irfa.2014.11.001.

Bekaert, G., Hodrick, R. J., \& Zhang, X. (2008). International Stock Return Co-Movements. The Journal of Finance, 64(6), 2591-2626. https://doi.org/10.111/j.15406261.2009.01512.x.

Bernanke, B. S. \& Gertler, M. (2001). Should Central Banks Respond to Movements in Asset Prices?. The American Economic Review. 91(2), 253-257. https://doi.org/10.1257/aer.91.2.253.

Bjørnland, H. C. \& Leitemo, K. (2009). Identifying the Interdependence Between US Monetary Policy and the Stock Market. Journal of Monetary Economics, 56(2), 275-282. https://doi.org/10.1016/j.jmoneco.2008.12.001.

Bouakez, H. \& Normandin, M. (2010). Fluctuations in the Foreign Exchange Market: How Important Are Monetary Policy Shocks?. Journal of International Economics, 81(1), 139-153. https://doi.org/10.1016/j.jinteco.2009.11.007.

Caraiani, P. \& Călin, A. C. (2020). The Impact of Monetary Policy Shocks on Stock Market Bubbles International Evidence. Finance Research Letters, 34, 101268. https://doi.org/10.1016/j.frl.2019.08.016.

Chatziantoniou, I., Duffy, D., \& Filis, G. (2013). Stock Market Response to Monetary and Fiscal Policy Shocks: Multi-Country Evidence. Economic Modelling, 30, 754-769. https://doi.org/10.1016/j.econmod.2012.10.005.

De Bondt, G. J. (2005). Interest Rate Pass-Through: Empirical Results for the Euro Area. German Economic Review, 6(1), 37-78. https://doi.org/10.1111/j.14656485.2005.00121.x.

Fiebig, D.G. (2003). Seemingly Unrelated Regression. In Badi H. Baltagi. Companion to Theoritical Econometrics, (pp. 122-141). New Jersey: Blackwell Publishing Ltd. https://doi.org/10.1002/9780470996249.ch6.

Global Intelligence Alliance (GIA). (2012). Business Perspective on Emerging Markets 20122017. Retrieved September 172018 from https://www.m-brain.com/wpcontent/uploads/2015/04/9927.pdf.

Gong, P. \& Dai, J. (2017). Monetary Policy, Exchange Rate Fluctuation, and Herding Behavior 
in the Stock Market. Journal of Business Research, 76, 34-43. https://doi.org/10.1016/j.jbusres.2017.02.018.

Ioannidis, C. \& Kontonikas, A. (2008). The Impact of Monetary Policy On Stock Prices. $\begin{array}{llll}\text { Journal of } & \text { Policy } & \text { 30deling, } & \text { 33-53. }\end{array}$ https://doi.org/10.1016/j.jpolmod.2007.06.015.

Lawal, I., A., Somoye, R., O., Babajide, A., A., \& Nwanji, T., I. (2018). The Effect of Fiscal and Monetary Policies Interaction On Stock Market Performance: Evidence From Nigeria. Future Business Journal, 4(1), 16-33. https://doi.org/10.1016/j.fbj.2017.11.004.

Karagiannis, S., Panagopoulos, Y., \& Vlamis, P. (2010). Interest Rate Pass-Through In Europe and The US: Monetary Policy After The Financial Crisis. Journal of Policy Modeling, 32(3), 323-338. https://doi.org/10.1016/j.jpolmod.2010.02.006.

Kurov, A. (2010). Investor Sentiment and The Stock Market's Reaction to Monetary Policy.

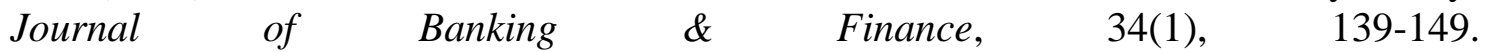
https://doi.org/10.1016/j.jbankfin.2009.07.010.

Laopodis, N. T. (2013). Monetary Policy and Stock Market Dynamics Across Monetary Regimes. Journal of International Money and Finance, 33, 381-406. https://doi.org/10.1016/j.jimonfin.2012.09.004.

Marinescu, I. I., Horobet, A., \& Lupu, R. (2018). Dichotomous Stock Market Reaction to Episodes of Rules and Discretion In The US Monetary Policy. Economic Modelling, 70, 56-66. https://doi.org/10.1016/j.econmod.2017.10.009.

Mobarek, A., Muradoglu, G., Mollah, S., \& Hou, A. J. (2016). Determinants of Time-Varying Co-Movements Among International Stock Markets During Crisis and Non-Crisis Periods. Journal of Financial Stability, 24, 1-11. https://doi.org/10.1016/j.jfs.2016.03.003.

Morana, C. \& Beltratti, A. (2008). Co-Movements In International Stock Markets. Journal of International Financial Markets, Institutions and Money, 18(1), 31-45. https://doi.org/10.1016/j.intfin.2006.05.001.

Neuhierl, A. \& Weber, M. (2019). Monetary Policy Communication, Policy Slope, And The Stock Market. Journal of Monetary Economics, 108, 140-155. https://doi.org/10.1016/j.jmoneco.2019.08.005.

Reuters. (2018). Data Stream Thomson Reuters. Retrieved December 312018 from https://www.reuters.com/markets/global-market-data.

Rocha, M. D. (2012). Interest Rate Pass-Through In Portugal: Interactions, Asymmetries and Heterogeneities. Journal of Policy Modeling, 34(1), 64-80. https://doi.org/10.1016/j.jpolmod.2011.07.010.

Wibowo, B. \& Lazuardi, W. (2016). Uji Empiris Mekanisme Transmisi Kebijakan Moneter: Interest Rate Pass-through Sektor Perbankan Indonesia. Jurnal Ekonomi dan Pembangunan Indonesia, 16(2). https://doi.org/10.21002/jepi.v16i2.629. 
Wibowo, B.

Monetary policy and stock market reaction: developed market and emerging market comparison

Zare, R. \& Azali, M. (2015). The Association Between Aggregated and Disaggregated Stock Prices With Monetary Policy Using Asymmetric Cointegration and Error-Correction Modeling Approaches. Review of Development Finance, 5(1), 64-69. https://doi.org/10.1016/j.rdf.2014.07.002.

Appendix 1. Panel Data Model Estimation Result

\begin{tabular}{lcccc}
\hline \multirow{2}{*}{ Panel } & \multicolumn{2}{c}{ Nominal Return } & \multicolumn{2}{c}{ Real Return } \\
\cline { 2 - 5 } & $\begin{array}{c}\text { Interest } \\
\text { Rate }\end{array}$ & $\begin{array}{c}\text { Foreign } \\
\text { Exchanges Rate }\end{array}$ & $\begin{array}{c}\text { Interest } \\
\text { Rate }\end{array}$ & $\begin{array}{c}\text { Foreign } \\
\text { Exchanges Rate }\end{array}$ \\
\hline G7 & $3.57^{* *}$ & 5.89 & $4.32^{* *}$ & 6.43 \\
Emerging Market & $7.83^{* *}$ & $12.37^{* *}$ & -3.12 & -4.31 \\
\hline
\end{tabular}

